\title{
OPTIMALISASI INTEGRASI SAPI, JAGUNG, DAN RUMPUT LAUT (PIJAR) PADA TEKNOLOGI PENGOLAHAN PAKAN TERNAK BERBASIS LIMBAH PERTANIAN JAGUNG - RUMPUT LAUT GUNA MENDUKUNG PROGRAM BUMI SEJUTA SAPI (BSS) DI NUSA TENGGARA BARAT
}

\author{
OPTIMIZING OF INTEGRATION OF SAPI, JAGUNG AND RUMPUT LAUT (PIJAR) ON THE \\ FEED TECHNOLOGY PROCESSING BASED ON MAIZE CROP RESIDUES - SEAWEED TO \\ SUPPORT BUMI SEJUTA SAPI PROGRAM (BSS) IN NUSA TENGGARA BARAT
}

\author{
Erin Ryantin Gunawan, Dedi Suhendra, dan Dhony Hermanto* \\ Fakultas Matematika dan Ilmu Pengetahuan Alam, Universitas Mataram, J1. Majapahit No. 62, Mataram, 83125
}

\section{INTISARI}

Penelitian ini bertujuan untuk mengetahui optimalisasi integrasi sapi, jagung, dan rumput laut (pijar) dengan pengolahan teknologi pakan ternak berbasis limbah pertanian jagung-rumput laut yang telah dilakukan guna mendukung Program Bumi Sejuta Sapi (BSS) di Nusa Tenggara Barat. Penelitian dilaksanakan di Kecamatan Bayan Kabupaten Lombok Utara - NTB pada bulan Juli hingga Desember 2012. Peningkatan kualitas pakan meliputi nilai nutrisi dan daya simpannya diperoleh melalui fermentasi jerami jagung yang diikuti dengan suplementasi pakan menggunakan bahan tambahan pakan rumput laut. Perubahan kualitas pakan diketahui dengan membandingkan kadar karbohidrat (gula pereduksi), protein kasar, lemak, serat kasar, mineral (Ca, Fe, dan P), lignin, selulosa, dan hemiselulosa antara pakan ternak komplit, jerami jagung terfermentasi-rumput laut, dan jerami jagung non fermentasi. Fermentasi jerami jagung dilakukan dengan melakukan variasi perbandingan kadar jerami jagung, probiotik (starbio dan EM4), urea dan molases, meliputi PG1, PG2, PG3, PG4, dan PG5. Data masing-masing parameter diuji dengan uji ANOVA satu jalur untuk mengetahui signifikansi efek dari beberapa perlakuan pakan. Uji organoleptik yang dilakukan meliputi warna dan bau. Suhu dan keasaman pakan pada masing masing perlakuan juga diukur. Variabel pada ternak sapi yang diukur adalah perubahan lingkar dada serta panjang badan sapi akibat pemberian pakan dengan jumlah yang ditentukan dalam kurun waktu 5 minggu. Sapi yang digunakan adalah 5 ekor sapi Bali jantan umur 18-24 bulan. Hasil penelitian menunjukkan bahwa jerami jagung fermentasi berkualitas baik memiliki bentuk seperti dalam keadaan segar yaitu memiliki warna coklat kekuning-kuningan, aroma bau yang khas, dan berdaya simpan lama (hingga bulan ke-2 penyimpanan). Hasil uji ANOVA satu jalur pada masing-masing parameter gizi menunjukkan bahwa perbedaan perlakuan fermentasi menghasilkan kadar gizi yang signifikan berbeda. Proses fermentasi jerami jagung meningkatkan protein kasar, gula pereduksi, dan menurunkan serat kasar, lemak, mineral (Ca, Fe dan P), lignin, selulosa, dan hemiselulosa. Peningkatan kadar karbohidrat tertinggi diperoleh pada perlakuan PG5 yaitu 15,50\%, sedangkan peningkatan kadar protein tertinggi diperoleh pada PG3, yaitu 11,60\%. Pemberian jerami jagung yang disuplementasi rumput laut 10\% selama 5 minggu dapat menghasilkan perubahan lingkar dada dan panjang badan sapi tertinggi pada perlakuan PG5+R.

(Kata kunci: Limbah pertanian, Jerami jagung, Rumput laut, Pakan)

\begin{abstract}
The aim of this study was to examine the integration of sapi, jagung and rumput laut (pijar) on the feed technology processing based on maize crop residues-seaweed has been done to support the program of Bumi Sejuta Sapi (BSS) in Nusa Tenggara Barat Province. The study was conducted in Bayan District, Lombok Utara Regency, in July-December 2012. Improvement of the feed quality (nutritive value and storage time) was obtained by fermenting maize straw, followed by supplementation feed with feed additive, such as seaweed. Effects of treatment were determined by comparing the levels of carbohydrates (reducing sugars), crude protein, extract ether, crude fiber, minerals ( $\mathrm{Ca}, \mathrm{Fe}$ and P), lignin, cellulose and hemicellulose content of the complete feed, fermented maize strawseaweed, and non-fermented maize straw. The process of maize straw fermentations were done by applying different levels of maize straw, probiotics (starbio and EM4), urea and molasses, such as PG1, PG2, PG3, PG4 and PG5. Data obtained were analyzed using ANOVA test. Organoleptic test was conducted on the color and odor. Temperature and acidity of feed in each treatment were also measured. The respond of animal to the feed treatments were determined by chest circumference and body length meassurement. The animals used in this study were 5 male Bali cattles, at 18-24 months of age. Results show that the good quality fermented maize straw had specifications of fresh, yellowish brown in color, specific flavor and longer storage time (until the second month of storage). The fermentation process
\end{abstract}

\footnotetext{
*Korespondensi (corresponding author):

Telp. +62 8139505 5517, Fax. (0370) 634708/646506

Email: dhony.hermanto@gmail.com
} 
increased crude protein, reducing sugars levels, as well as lowered crude fiber, fat, minerals (Ca, Fe and P), lignin, cellulose and hemicellulose contents of maize straw. The highest improvement in carbohydrates level was performed by PG5(15.50\%), whereas the highest improvement in protein level was obtained at PG3 (11.60\%). The highest increasment of chest circumference and body length were occurred on cattle feed maize straw with 10\% seaweed supplementation in 5 weeks.

(Keywords: Maize crop residues, Maize straw, Seaweed, Feed)

\section{Pendahuluan}

Program Nusa Tenggara Barat (NTB) sebagai Bumi Sejuta Sapi (BSS) merupakan program percepatan pengembangan peternakan sapi menuju populasi satu juta ekor dalam waktu lima tahun (2009-2013) (Pemprov NTB, 2009). Provinsi NTB kedepannya diharapkan menjadi propinsi surplus sapi yang dikembangkan terintegrasi dengan sektor lainnya guna mendukung ketahanan pangan berupa protein hewani. Hal ini selaras dengan program Masterplan Percepatan dan Perluasan Pembangunan Ekonomi Indonesia (MP3EI) yang menjadikan NTB sebagai wilayah pengembangan sektor pertanian dan peternakan.

Usaha pengembangan peternakan sapi perlu didukung dengan ketersediaan pakan yang berkualitas dalam jumlah yang cukup sepanjang tahun. Namun demikian sampai saat ini terbatasnya ketersediaan pakan hijauan pada musim kemarau dan rendahnya daya beli peternak terhadap pakan komersial (konsentrat) yang berkualitas juga masih menjadi kendala utama, sehingga perlu mencari alternatif pakan ternak yang memanfaatkan sumber daya lokal seperti jerami jagung yang merupakan limbah pertanian yang banyak terdapat di pulau Lombok. Akan tetapi, pakan ternak jenis ini memiliki kandungan nutrisi dan kecernaan yang rendah bila dimanfaatkan secara langsung sehingga diperlukan pengolahan dan penyusunan serta suplementasi pakan sehingga memiliki nilai nutrisi yang setara dengan pakan komersial.

Proses fermentasi merupakan salah satu upaya meningkatkan daya cerna dan daya simpan pakan jerami jagung. Poses fermentasi menggunakan biostarter untuk mempercepat peningkatan kualitas pakan dan untuk penyimpanan jangka panjang sehingga dapat mengatasi kesulitan dalam mendapatkan pakan hijauan pada musim kemarau (Matondang dan Fadwiwati, 2005; Mathius, 2003; Haryanto, 2003). Jerami pakan ternak dapat disuplementasi dengan bahan tambahan seperti rumput laut untuk meningkatkan nilai gizi pakan secara keseluruhan. Rumput laut sebagai sumber daya lokal NTB mempunyai kandungan nutrisi lebih lengkap bila dibandingkan dengan jerami. Selain karbohidrat, protein, lemak (Gunawan, 2011) dan serat, rumput laut juga mengandung enzim, asam nukleat, asam amino, vitamin $(\mathrm{A}, \mathrm{B}, \mathrm{C}, \mathrm{D}, \mathrm{E}$, dan K) dan mineral seperti kalsium (Ca), selenium $(\mathrm{Se})$, besi $(\mathrm{Fe})$, magnesium $(\mathrm{Mg})$ dan natrium $(\mathrm{Na})$ (Istini et al., 1986). Kandungan nutrisi rumput laut yang lebih lengkap ini tidak dimiliki pakan hijauan kering, seperti jerami padi dan jerami jagung walaupun ada beberapa kadar nutrisi yang lebih rendah, seperti lemak dan serat kasar.

Penelitian ini bertujuan untuk melakukan kajian pengolahan, penyusunan dan suplementasi pakan yang berkualitas tinggi dan berdaya simpan lama dengan harga terjangkau sehingga meningkatkan produktivitas ternak sapi guna mendukung ketahanan pangan nasional berupa protein hewani. Selain itu ransum pakan ternak ini dapat dikemas dan dikomersilkan sehingga dapat membantu peternak menyediakan pakan ternak yang berkualitas dengan harga terjangkau.

\section{Materi dan Metode}

Penelitian yang berkaitan dengan penentuan kadar nutrisi pakan dilakukan di Laboratorium Kimia dan Laboratorium Kimia Analitik FMIPA Universitas Mataram. Pengolahan limbah jerami jagung dilakukan di lahan milik kelompok tani di Kecamatan Bayan, Kabupaten Lombok Utara, Propinsi Nusa Tenggara Barat. Penelitian dilakukan pada bulan Juli hingga Desember 2012.

Bahan-bahan yang digunakan adalah jerami jagung kering (yang berasal dari lahan pertanian di Kec. Bayan), rumput laut (Euchema spinosum), EM4, starbio, urea, molases dan reagen pereaksi penentuan kadar karbohidrat (gula pereduksi), protein, lemak, serat kasar, lignin, selulosa, dan hemiselulosa.

Tahap 1. Identifikasi kandungan nutrisi limbah pertanian jagung-rumput laut. Preparasi sampel, limbah pertanian berupa jerami jagung kering diblender dengan kecepatan tinggi begitu pula dengan rumput laut. Pengukuran kadar komposisi limbah pertanian jagung-rumput laut antara lain: kadar karbohidrat (gula pereduksi), protein, lemak, serat, mineral (Ca, Fe, dan $\mathrm{P}$ ), lignin, selulosa, dan hemiselulosa diukur menggunakan prosedur standar.

Tahap 2. Pengolahan pakan ternak dan identifikasi kandungan nutrisinya. Jerami jagung difermentasi secara biologi menggunakan urea, biostarter (starbio dan EM4) dan molases. Pakan 
yang akan diawetkan diproses dari bahan baku berupa jerami jagung dengan kadar air berkisar antara 10-15\%, kemudian dimasukkan dalam kantong plastik kedap udara. Proses fermentasi dilakukan di tempat teduh (terlindungi dari sinar matahari) dalam waktu 3 minggu. Proses fermentasi jerami jagung dengan 5 variasi, yaitu:

PG1 $=$ jerami jagung difermentasi menggunakan urea : molases $(10: 1,5)$

PG2 $=$ jerami jagung difermentasi menggunakan starbio : molases $(10: 1,5)$

PG3 $=$ jerami jagung difermentasi menggunakan starbio : urea : molases $(10: 1,5: 1,5)$

PG4 $=$ jerami jagung difermentasi menggunakan EM-4 : molases $(10: 1,5)$

PG5 $=$ jerami jagung difermentasi menggunakan EM-4 : urea : molases $(10: 1,5: 1,5)$.

Molases yang digunakan diencerkan $10 \mathrm{cc}$ dalam $1 \mathrm{~L}$ air. Setelah proses fermentasi dilakukan, rumput laut kering yang telah dihaluskan disuplementasikan pada jerami jagung terfermentasi dengan level $10 \%$. Selanjutnya, campuran pakan yang sudah jadi dianalisis kadar karbohidrat (gula pereduksi), protein, lemak, serat, mineral $(\mathrm{Ca}, \mathrm{Fe}$, dan P), lignin, selulosa, dan hemiselulosa menggunakan prosedur standar. Penentuan kadar dilakukan pada 3 sampel berbeda pada masingmasing perlakuan dan parameter. Data masing- masing parameter diuji menggunakan uji ANOVA satu jalur untuk mengetahui signifikansi efek dari beberapa perlakuan pakan.

Uji organoleptik yang dilakukan meliputi warna dan bau pakan. Pengukuran suhu dan keasaman pakan juga dilakukan. Sedangkan variabel yang diukur adalah perubahan lingkar dada dan panjang badan sapi akibat pemberian pakan dengan jumlah yang ditentukan dalam kurun waktu 5 minggu. Sapi yang digunakan dalam penelitian ini adalah 5 ekor sapi Bali jantan, berumur 18-24 bulan dengan ketentuan 1 ekor sapi untuk masing-masing perlakuan. Pakan kering diberikan pada pagi hari (satu kali sehari) selama 5 minggu dengan masa penyesuaian 1 minggu. Pakan kering yang diberikan pada minggu pertama hingga minggu kelima berturut-turut adalah $4 \mathrm{~kg} ; 4,5 \mathrm{~kg} ; 5 \mathrm{~kg} ; 6 \mathrm{~kg}$; dan $6,5 \mathrm{~kg}$ per hari. Uji daya simpan ransum pakan dilakukan untuk mengetahui kandungan nutrisi pakan setelah penyimpanan dalam kurun waktu 2 bulan. Ransum pakan disimpan ditempat terlindungi cahaya matahari dan diukur nutrisinya setiap bulan.

\section{Hasil dan Pembahasan}

\section{Fermentasi jerami jagung}

Data Tabel 1 menunjukkan bahwa kadar gizi jerami jagung non fermentasi berbeda signifikan dengan jerami jagung setelah perlakuan fermentasi.

Tabel 1. Nilai gizi rumput laut, jerami jagung fermentasi dan non fermentasi (nutritive value of seaweed, fermented maize straw and nonfermented maize straw)

\begin{tabular}{|c|c|c|c|c|c|c|c|}
\hline \multirow{3}{*}{ Parameter } & \multirow{3}{*}{$\begin{array}{l}\text { Rumput } \\
\text { laut kering } \\
\text { (seaweed) }\end{array}$} & \multicolumn{6}{|c|}{ Jerami jagung (maize straw) } \\
\hline & & \multirow{2}{*}{$\begin{array}{l}\text { Non fermentasi } \\
\text { (nonfermented) }\end{array}$} & \multicolumn{5}{|c|}{ Fermentasi (fermented) } \\
\hline & & & PG 1 & PG 2 & PG 3 & PG 4 & PG 5 \\
\hline $\begin{array}{l}\text { Karbohidrat (\%) (gula } \\
\text { pereduksi) (carbohydrate } \\
(\%)(\text { reducing sugar }))^{*}\end{array}$ & 13,03 & 12,11 & 14,34 & 13,42 & 15,02 & 13,48 & 15,50 \\
\hline Protein $(\%)^{*}$ & 5,04 & 6,20 & 10,87 & 6,59 & 11,60 & 6,12 & 11,27 \\
\hline $\operatorname{Lemak}(\%)(f a t(\%))^{*}$ & 0,13 & 2,65 & 2,15 & 1,75 & 2,26 & 2,13 & 2,05 \\
\hline $\begin{array}{l}\text { Serat kasar }(\%) \text { (crude } \\
\text { fiber }(\%))^{*}\end{array}$ & 1,42 & 25,58 & 22,85 & 23,22 & 22,01 & 23,33 & 21,64 \\
\hline $\begin{array}{l}\text { Kadar air }(\%)(\text { water } \\
\text { content }(\%))^{*}\end{array}$ & 12,47 & 10,82 & 9,29 & 15,04 & 9,18 & 9,43 & 8,01 \\
\hline $\mathrm{Ca}(\mathrm{ppm})^{*}$ & 50,46 & 0,82 & 0,36 & 0,50 & 0,44 & 0,31 & 0,36 \\
\hline $\mathrm{Fe}(\mathrm{ppm})^{*}$ & 0,14 & 0,05 & 0,05 & 0,19 & 0,13 & 0,058 & 0,07 \\
\hline $\mathrm{N}(\mathrm{ppm}) *$ & 0,80 & 0,99 & 1,74 & 1,05 & 1,86 & 0,98 & 1,80 \\
\hline $\mathrm{P}(\mathrm{ppm})^{*}$ & 5,19 & 0,32 & 0,16 & 0,20 & 0,28 & 0,17 & 0,21 \\
\hline Koloid (karagenan) (\%) & 65,70 & - & - & - & - & - & - \\
\hline
\end{tabular}


Teknologi fermentasi dapat meningkatkan daya cerna pakan karena dapat memecah serat kasar jerami jagung. Sedangkan substitusi bahan pelengkap seperti rumput laut diperlukan untuk meningkatkan kualitas pakan.

Secara fisik terdapat perbedaan jerami jagung fermentasi dan non fermentasi. Jerami jagung fermentasi lebih rapuh dan memiliki bau yang khas (lebih wangi). Perbedaan ini disebabkan jerami jagung fermentasi telah mengalami perombakan struktur baik secara fisik, kimia, dan biologi dari struktur kompleks menjadi lebih sederhana, sehingga kecernaan pakan menjadi lebih tinggi. Jerami jagung mengandung lignoselulosa dan lignohemiselulosa yang sulit dicerna. Mikroorganisme fermenter mendegradasi lignin yang melapisi selulosa dan hemiselulosa menjadi senyawa fenolik (Srihardyastutie et al., 2011). Senyawa fenolik tersebut bersama alkohol diduga menghasilkan bau khas pada jerami jagung terfermentasi.

Perbandingan komposisi nutrisi jerami jagung setelah fermentasi dan sebelum fermentasi terdapat pada Tabel 1. Hasil uji ANOVA satu jalur pada masing-masing parameter gizi menunjukkan bahwa perbedaan perlakuan menghasilkan kadar gizi yang berbeda. Kenaikan kadar protein terjadi pada jerami jagung yang difermentasi, dimana fermentasi yang menggunakan urea dan biostarter (PG3 dan PG5) memiliki protein yang tertinggi diikuti oleh fermentasi yang menggunakan urea (PG1) (Tabel 1). Hal ini disebabkan urea merupakan sumber nitrogen dan karbon yang merupakan makanan bagi mikroorganisme, sehingga fermentasi dapat berjalan dengan baik. Keberadaan mikroorganisme dalam biostarter (starbio dan EM4) juga berimplikasi pada peningkatan protein pakan hasil fermentasi karena kandungan asam amino-asam amino mikro- organisme tersebut. Pemberian urea juga terbukti meningkatkan kecernaan pakan. Chuzaemi dan Soejono (1987), menggunakan urea 6 dan 8\% pada jerami padi secara in-vivo dapat meningkatkan kecernaan bahan kering, bahan organik, dan energi. Setelah terurai menjadi $\mathrm{NH}_{3}$ dan $\mathrm{CO}_{2}, \mathrm{NH}_{3}$ dengan molekul air akan mengalami hidrolisis menjadi $\mathrm{NH}_{4}{ }^{+}$dan $\mathrm{OH}^{-}$. Suasana alkali yang terjadi (gugus $\mathrm{OH}^{-}$) dapat memutus ikatan hidrogen antara oksigen karbon nomor dua molekul glukosa satu dengan oksigen karbon nomor enam molekul glukosa lain yang terdapat pada selulosa, lignoselulosa, dan lignohemiselulosa karena ikatan tersebut bersifat labil alkali.

Penggunaan urea pada proses fermentasi juga dapat menekan pertumbuhan jamur. Hal ini berkaitan dengan kadar air jerami hasil fermentasi. Pada fermentasi PG2 tidak digunakan urea sehingga kadar airnya lebih tinggi dibanding perlakuan yang lain. Hal ini juga terlihat dari penampilan fisik jerami yaitu lebih lembab dibanding perlakuan yang lainnya. Hasil peruraian urea yaitu $\mathrm{NH}_{3}$ dengan adanya molekul air berkesetimbangan membentuk $\mathrm{NH}_{4}^{+}$dan $\mathrm{OH}^{-}$sehingga kadar air berkurang.

Peningkatan karbohidrat dan penurunan serat mengindikasikan terjadinya pemecahan serat (selulosa atau hemiselulosa) menjadi karbohidrat yang lebih sederhana. Sebagian karbohidrat ini akan difermentasi menjadi alkohol dan $\mathrm{CO}_{2}$ oleh bakteri Saccharomyces cerevisiae yang terdapat dalam biostarter. Peningkatan karbohidrat tertinggi diperoleh pada perlakuan PG3 dan PG5 yang menggunakan biostrarter (Starbio dan EM4). Hal ini juga didukung dengan turunnya kadar lignin, selulosa, dan hemiselulosa setelah fermentasi, seperti ditunjukkan pada Gambar 1.

Pada Gambar 1 menunjukkan bahwa fermentasi dapat menurunkan kadar lignin, selulosa,

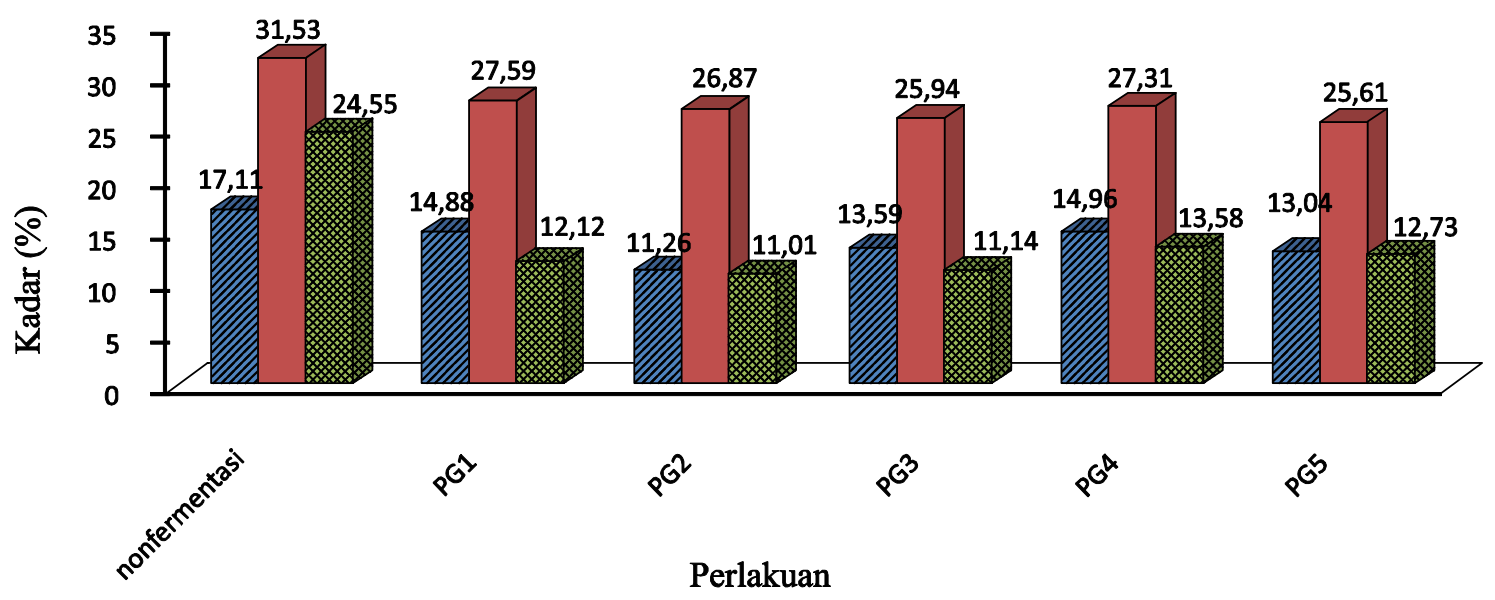

Hemiselulosa (\%)

Selulosa (\%)

Lignin (\%)

Gambar 1. Kadar lignin, selulosa, dan hemiselulosa pada jerami jagung nonfermentasi dan fermentasi (lignin,cellulose and hemicellulose levels of nonfermented maize straw and fermented maize straw). 
dan hemiselulosa pada jerami jagung yang mengindikasikan bahwa terjadi pemecahan lignin. Penurunan kadar lignin paling tinggi terdapat pada perlakuan yang menggunakan biostarter baik EM4 maupun starbio (PG2 sampai PG5). Diduga selama proses fermentasi terjadi pemutusan ikatan lignoselulosa dan lignohemiselulosa jerami jagung. Mikroba lignolitik dalam starter mikroba membantu perombakan ikatan lignoselulosa sehingga selulosa dan lignin dapat terlepas dari ikatan tersebut oleh enzim lignase. Penurunan kadar selulosa pada data lebih rendah dibandingkan penurunan kadar lignin. Hal ini dapat dipahami mengingat lignin merupakan benteng pelindung yang membungkus dan mengikat selulosa secara fisik sehingga menghalangi enzim selulase bekerja maksimal pada substrat. Dengan menurunnya kadar selulosa menunjukkan telah terjadi pemecahan selulosa dinding sel sehingga pakan akan lebih mudah dicerna oleh ternak.

Penurunan lemak kasar dan mineral $(\mathrm{Ca}, \mathrm{Fe}$, dan P) diduga adanya pemanfaatan senyawa dan mineral tersebut untuk pertumbuhan dan perkembangan mikroorganisme. Trace elemen merupakan salah satu pelengkap nutrisi bagi proses metabolisme mikroorganisme agar proses fermentasi dapat berlangsung dengan baik.

\section{Ransum pakan jerami jagung dan rumput laut}

Jerami jagung terfermentasi dicampur dengan rumput laut dengan perbandingan $10: 1$. Penambahan rumput laut dapat mengatasi penurunan mineral yang terjadi saat fermentasi. Walaupun kadar lemak kasar rumput laut rendah, penambahan rumput laut dapat meningkatkan nilai lemak kasar ransum meskipun tidak signifikan. Kandungan nutrisi ransum merupakan jumlah dari kadar nutisi jerami jagung dan nutrisi rumput laut, seperti disajikan pada Tabel 2. Hasil uji ANOVA satu jalur pada masing-masing parameter gizi menunjukkan bahwa perbedaan perlakuan fermentasi menghasilkan kadar gizi yang berbeda.

\section{Uji coba pemanfaatan ransum jerami jagung fermentasi dan rumput laut \\ Uji organoleptik. Uji organoleptik yang di-} lakukan meliputi warna dan bau. Suhu dan keasaman pakan juga diukur seperti disajikan pada Tabel 3. Variabel yang diukur untuk mengetahui palatabilitas ransum adalah konsumsi pakan harian yang disajikan pada Tabel 4 .

Waktu konsumsi yang pendek mengindikasikan ternak menyukai ransum jerami jagung fermentasi dan rumput laut seperti terlihat pada Tabel 3. Hal ini didukung dengan konsumsi pakan bahan kering harian rata-rata seperti terlihat pada Tabel 4. Kenaikan konsumsi dari ransum jerami jagung fermentasi dan rumput laut yang diberikan dengan jumlah tertentu menunjukkan bahwa palatabilitasnya cukup baik artinya ransum ini sangat disukai oleh ternak sehingga dapat dipertimbangkan sebagai pakan penggemukan sapi.

Pertambahan ukuran sapi. Perubahan ukuran tubuh sapi seperti lingkar dada dan panjang badan merupakan indikator pertumbuhan sapi. Kedua dimensi tersebut merupakan dimensi yang paling sering digunakan sebagai penduga berat sapi. Data ukuran lingkar dada dan panjang badan sapi

Tabel 2. Nilai gizi ransum jerami jagung fermentasi dan rumput laut (nutritive value of fermented maize straw and seaweed)

\begin{tabular}{lccrrr}
\hline \hline \multirow{2}{*}{ Parameter } & \multicolumn{5}{c}{ Fermentasi (fermented) } \\
\cline { 2 - 6 } & PG 1+R & PG 2+R & PG 3+R & PG 4+R & PG 5+R \\
\hline Karbohidrat (\%) (carbohydrate & 15,64 & 14,72 & 16,32 & 14,78 & 16,80 \\
(\%)* & & & & & \\
Protein (\%)* & 11,37 & 7,09 & 12,10 & 6,62 & 11,77 \\
Lemak (\%) (fat (\%))* & 2,16 & 1,76 & 2,27 & 2,14 & 2,06 \\
Serat kasar (\%) (crude fiber (\%))* & 22,99 & 23,36 & 22,15 & 23,47 & 21,78 \\
Kadar air (\%) (water content (\%))* & 10,54 & 16,29 & 10,43 & 10,68 & 9,26 \\
Ca (ppm)* & 5,41 & 5,55 & 5,49 & 5,36 & 5,41 \\
Fe (ppm)* & 0,06 & 0,20 & 0,14 & 0,06 & 0,08 \\
N (ppm)* & 1,82 & 1,13 & 1,94 & 1,06 & 1,88 \\
P (ppm)* & 0,68 & 0,72 & 0,80 & 0,69 & 0,73 \\
\hline
\end{tabular}

* Berbeda signifikan pada uji ANOVA satu jalur pada masing masing parameter dengan $\alpha=0,05$ dan $\mathrm{df}=4 ; 10$ (significantly different in ANOVA one lane on each parameter with $\alpha=0.05$ and $d f=4 ; 10$ ). 
Tabel 3. Uji organoleptik ransum jerami jagung fermentasi dan rumput laut (organoleptic test of fermented maize straw and seaweed)

\begin{tabular}{|c|c|c|c|c|c|}
\hline \multirow{2}{*}{ Parameter } & \multicolumn{5}{|c|}{ Ransum pakan (feed rations) } \\
\hline & PG $1+\mathrm{R}$ & PG $2+\mathrm{R}$ & PG $3+R$ & PG 4+R & PG 5+R \\
\hline Warna (color) & $\begin{array}{l}\text { Kuning } \\
\text { kecoklatan } \\
\text { (tawny) }\end{array}$ & $\begin{array}{l}\text { Kuning } \\
\text { kecoklatan } \\
\text { (tawny) }\end{array}$ & $\begin{array}{l}\text { Kuning } \\
\text { kecoklatan } \\
\text { (tawny) }\end{array}$ & $\begin{array}{l}\text { Kuning } \\
\text { kecoklatan } \\
\text { (tawny) }\end{array}$ & $\begin{array}{l}\text { Kuning } \\
\text { kecoklatan } \\
\text { (tawny) }\end{array}$ \\
\hline $\mathrm{Bau}($ odor) & $\begin{array}{l}\text { Wangi } \\
\text { (fragrant) }\end{array}$ & $\begin{array}{l}\text { Wangi, agak } \\
\text { asam (fragrant, } \\
\text { sourish) }\end{array}$ & $\begin{array}{l}\text { Wangi } \\
\text { (fragrant) }\end{array}$ & $\begin{array}{l}\text { Wangi, agak } \\
\text { asam (fragrant, } \\
\text { sourish) }\end{array}$ & $\begin{array}{l}\text { Wangi } \\
\text { (fragrant) }\end{array}$ \\
\hline Suhu $\left({ }^{\circ} \mathrm{C}\right)\left(\right.$ temperature $\left.\left({ }^{\circ} \mathrm{C}\right)\right)$ & 26,3 & 26,8 & 27 & 27,3 & 27 \\
\hline Keasaman (acidity) & 5 & 4 & 5 & 4 & 5 \\
\hline $\begin{array}{l}\text { Waktu konsumsi }(4 \mathrm{~kg}) \text { (time } \\
\text { consumption }(4 \mathrm{~kg}) \text { ) }\end{array}$ & $\begin{array}{l}83 \text { menit } \\
(83 \text { minute })\end{array}$ & $\begin{array}{l}80 \text { menit ( } 80 \\
\text { minute) }\end{array}$ & $\begin{array}{l}75 \text { menit } \\
(75 \text { minute })\end{array}$ & $\begin{array}{l}79 \text { menit ( } 79 \\
\text { minute) }\end{array}$ & $\begin{array}{l}76 \text { menit ( } 76 \\
\text { minute) }\end{array}$ \\
\hline
\end{tabular}

Tabel 4. Rata-rata konsumsi pakan bahan kering harian yang diberikan pada ternak (daily complete feed consumption mean of cattle)

\begin{tabular}{cccccc}
\hline \hline \multirow{2}{*}{$\begin{array}{c}\text { Perlakuan } \\
\text { treatment })\end{array}$} & \multicolumn{4}{c}{ Konsumsi pakan ransum (dalam kg/hari) (ration offeed consumption (in kg/day)) } \\
\cline { 2 - 6 } & $\begin{array}{c}\text { Minggu ke-1 } \\
(\text { week-1) }\end{array}$ & $\begin{array}{c}\text { Minggu ke-2 } \\
(\text { week-2) }\end{array}$ & $\begin{array}{c}\text { Minggu ke-3 } \\
(\text { week-3) }\end{array}$ & $\begin{array}{c}\text { Minggu ke-4 } \\
\text { (week-4) }\end{array}$ & $\begin{array}{c}\text { Minggu ke-5 } \\
\text { (week-5) }\end{array}$ \\
\hline PG 1+R & 4,0 & 4,5 & 5,0 & 6,0 & 6,5 \\
PG 2+R & 4,0 & 4,5 & 5,0 & 6,0 & 6,5 \\
PG 3+R & 4,0 & 4,5 & 5,0 & 6,0 & 6,5 \\
PG 4+R & 4,0 & 4,5 & 5,0 & 6,0 & 6,5 \\
PG 5+R & 4,0 & 4,5 & 5,0 & 6,0 & 6,5 \\
\hline
\end{tabular}

Tabel 5. Rata-Rata data panjang badan (PB) dan lingkar dada (LD) sapi (dalam $\mathrm{cm})$ (chest circumference and body length mean of cows $(\mathrm{cm}))$

\begin{tabular}{|c|c|c|c|c|c|c|c|c|c|c|c|c|}
\hline \multirow{2}{*}{$\begin{array}{c}\text { Ransum } \\
\text { pakan } \\
\text { (feed } \\
\text { rations) }\end{array}$} & \multicolumn{2}{|c|}{$\begin{array}{l}\text { Awal } \\
\text { (early) }\end{array}$} & \multicolumn{2}{|c|}{$\begin{array}{l}\text { Minggu ke-1 } \\
\text { (week-1) }\end{array}$} & \multicolumn{2}{|c|}{$\begin{array}{c}\text { Minggu ke-2 } \\
\text { (week-2) }\end{array}$} & \multicolumn{2}{|c|}{$\begin{array}{c}\text { Minggu ke-3 } \\
(\text { week-3) }\end{array}$} & \multicolumn{2}{|c|}{$\begin{array}{c}\text { Minggu ke-4 } \\
(\text { week-4) }\end{array}$} & \multicolumn{2}{|c|}{$\begin{array}{c}\text { Minggu ke-5 } \\
\text { (week-5) }\end{array}$} \\
\hline & LD & PB & LD I & PB I & LD II & PB II & LD III & PB III & LD IV & PB IV & LD V & PB V \\
\hline PG $1+\mathrm{R}$ & 159,2 & 111,4 & 160,5 & 112,4 & 162,3 & 6 & 164,2 & 8 & 166,1 & 116,1 & 168,0 & 117,4 \\
\hline PG $2+\mathrm{R}$ & 155,6 & 108,9 & 156,7 & 109,7 & 158,3 & 110,8 & 160,1 & 112,1 & 161,9 & 113,3 & 163,7 & 114,7 \\
\hline PG $3+\mathrm{R}$ & 157,9 & 110,5 & 159,4 & 111,6 & 161,3 & 112,9 & 163,2 & 114,3 & 165,1 & 115,7 & 167,1 & 116,9 \\
\hline PG 4+R & 152,8 & 107,0 & 153,9 & 107,9 & 155,4 & 108,8 & 157,2 & 110,0 & 158,9 & 111,9 & 160,9 & 112,9 \\
\hline PG 5+R & 156,3 & 109,4 & 157,8 & 110,3 & 159,6 & 111,8 & 161,5 & 113,3 & 163,6 & 114,4 & 165,7 & 115,7 \\
\hline
\end{tabular}

yang diamati dalam kurun waktu 5 minggu disajikan pada Tabel 5 dan rata-rata perubahannya disajikan pada Tabel 6.

Pada Tabel 5 dan 6 terlihat rata-rata perubahan panjang badan (PB) dan lingkar dada (LD) sapi pada minggu pertama belum terlalu baik. Hal ini disebabkan minggu pertama merupakan waktu penyesuaian pakan, diindikasikan dengan jumlah konsumsi ransum jerami jagung fermentasi dan rumput laut yang masih rendah (Tabel 4). Pada minggu-minggu berikutnya ternak sapi telah terbiasa mengonsumsi ransum jerami jagung fermentasi dan rumput laut sehingga mampu mengonsumsi pakan dalam jumlah yang lebih banyak. Hal ini berimplikasi pada peningkatan PB dan LD sapi dengan nilai tertinggi pada pemberian PG5 dan rumput laut (PG5+R). 
Tabel 6. Rata-rata perubahan panjang badan (PB) dan lingkar dada (LD) sapi (dalam $\mathrm{cm}$ ) (changes chest circumference and body length mean of cows $(\mathrm{cm})$ )

\begin{tabular}{ccccccccccc}
\hline \hline $\begin{array}{c}\text { Ransum } \\
\text { pakan } \\
\text { (feed }\end{array}$ & \multicolumn{2}{c}{$\begin{array}{c}\text { Minggu ke-1 } \\
\text { (week-1) }\end{array}$} & \multicolumn{2}{c}{$\begin{array}{c}\text { Minggu ke-2 } \\
\text { (week-2) }\end{array}$} & \multicolumn{2}{c}{$\begin{array}{c}\text { Minggu ke-3 } \\
\text { (week-3) }\end{array}$} & \multicolumn{2}{c}{$\begin{array}{c}\text { Minggu ke-4 } \\
\text { (week-4) }\end{array}$} & \multicolumn{2}{c}{$\begin{array}{c}\text { Minggu ke-5 } \\
\text { (week-5) }\end{array}$} \\
\cline { 2 - 12 } rations $)$ & LD I & PB I & LD II & PB II & LD III & PB III & LD IV & PB IV & LD V & PB V \\
\hline PG 1+R & 1,3 & 1,0 & 1,8 & 1,2 & 1,9 & 1,2 & 1,9 & 1,3 & 1,9 & 1,3 \\
PG 2+R & 1,1 & 0,8 & 1,6 & 1,1 & 1,8 & 1,3 & 1,8 & 1,2 & 1,8 & 1,4 \\
PG 3+R & 1,5 & 1,1 & 1,9 & 1,3 & 1,9 & 1,4 & 1,9 & 1,4 & 2,0 & 1,2 \\
PG 4+R & 1,1 & 0,9 & 1,5 & 0,9 & 1,8 & 1,2 & 1,7 & 1,9 & 2,0 & 1,0 \\
PG 5+R & 1,5 & 0,9 & 1,8 & 1,5 & 1,9 & 1,5 & 2,1 & 1,1 & 2,1 & 1,3 \\
\hline
\end{tabular}

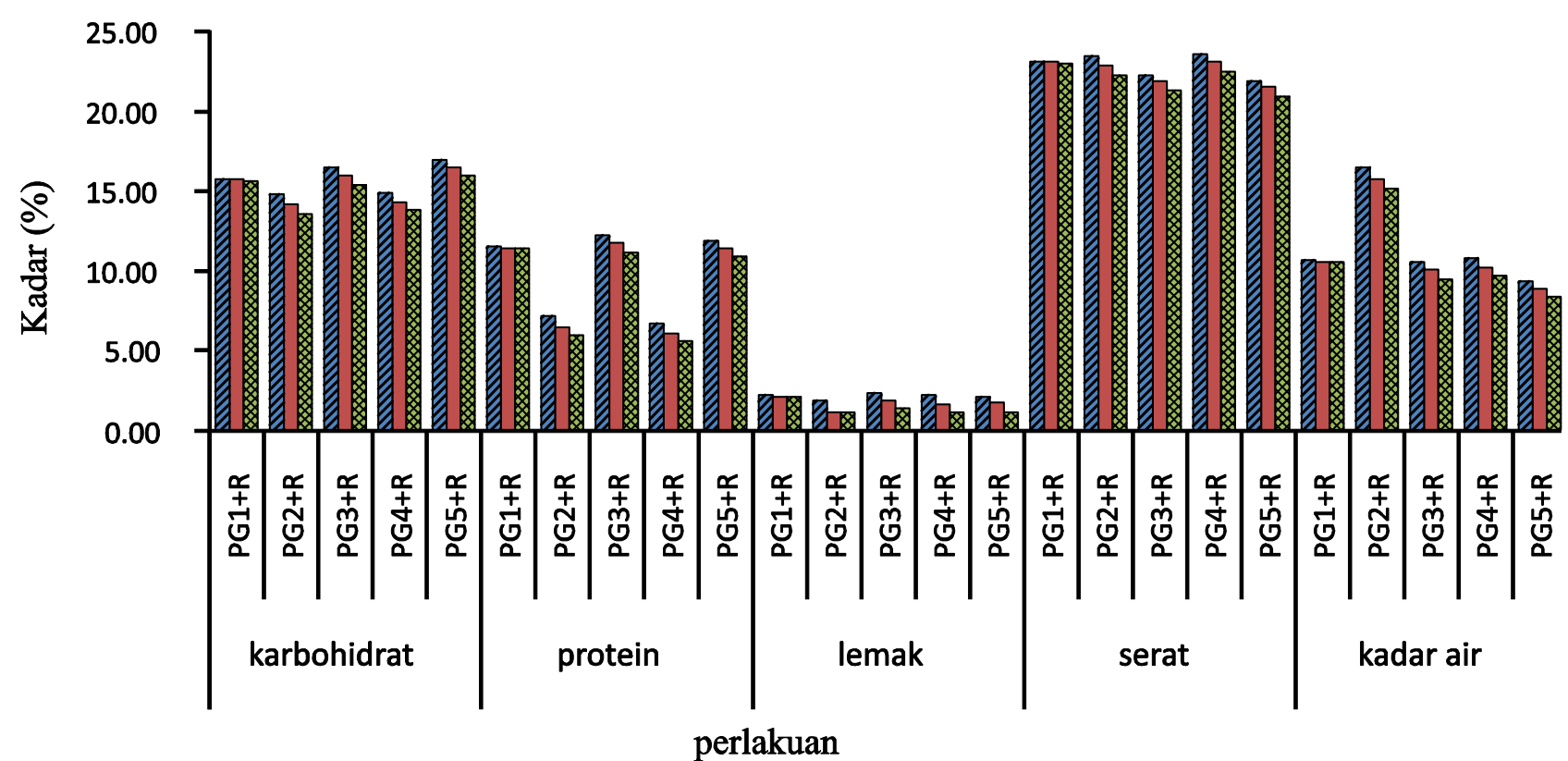

Wha bulan ke $0 \quad \square$ bulan ke 1

Gambar 3. Grafik uji daya simpan ransum pakan (storage periode test graph of complete feed).

Uji daya simpan ransum pakan. Uji daya simpan ransum pakan dilakukan untuk mengetahui kandungan nutrisi pakan setelah penyimpanan dalam kurun waktu tertentu. Gambar 3 menunjukkan secara umum tidak terdapat perubahan kadar nutrisi pakan ransum selama penyimpanan 2 bulan.

\section{Kesimpulan}

Jerami jagung fermentasi berkualitas baik memiliki bentuk seperti dalam keadaan segar yaitu memiliki warna coklat kekuning-kuningan, aroma bau yang khas dan berdaya simpan lama (kadar nutrisi tidak berubah signifikan hingga bulan ke-2 penyimpanan). Proses fermentasi jerami jagung dengan menggunakan biostarter (EM4 dan starbio) dan urea meningkatkan protein kasar, karbohidrat (gula pereduksi), dan menurunkan serat kasar, lemak, dan mineral $(\mathrm{Ca}, \mathrm{Fe}$, dan $\mathrm{P})$. Hasil uji ANOVA satu jalur pada masing-masing parameter gizi menunjukkan bahwa perbedaan perlakuan fermentasi menghasilkan kadar gizi yang signifikan berbeda. Proses fermentasi jerami jagung meningkatkan protein kasar, gula pereduksi dan menurunkan serat kasar, lemak, mineral $(\mathrm{Ca}, \mathrm{Fe}$, dan P), lignin, selulosa, dan hemiselulosa. Peningkatan kadar karbohidrat tertinggi diperoleh pada perlakuan PG5 yaitu $15,50 \%$, sedangkan peningkatan kadar protein tertinggi diperoleh oleh PG3, yaitu $11,60 \%$. Pemberian jerami jagung dengan suplementasi rumput laut dengan rasio 10 : 1 dengan jumlah yang ditentukan dalam kurun waktu 5 minggu dapat menghasilkan perubahan 
lingkar dada dan panjang badan sapi tertinggi pada perlakuan PG5+R. Kenaikan konsumsi dari ransum jerami jagung fermentasi dan rumput laut pada semua perlakuan menunjukkan bahwa palatabilitasnya cukup baik (sangat disukai oleh ternak) sehingga dapat dipertimbangkan sebagai pakan penggemukan sapi.

\section{Ucapan Terima Kasih}

Ucapan terima kasih penulis sampaikan kepada DIKTI atas bantuan dana penelitian melalui dana Program PENPRINAS MP3EI 2012 dan Sdr. Marzuni selaku ketua kelompok tani "SBP 212" Kecamatan Bayan yang telah membantu pelaksanaan penelitian di lapangan.

\section{Daftar Pustaka}

Chuzaemi, S. dan M. Soejono. 1987. Pengaruh urea amoniasi terhadap komposisi kimia dan nilai gizi jerami padi untuk ternak sapi Peranakan Onggole. Prosiding Limbah Pertanian sebagai Pakan dan Manfaat Lainnya. Available at http://peternakanuin.bogspot.com/2007/12/ perlakuan-silase-danamoniasi-daun.html. Accession date: 2 Januari, 2013.

Gunawan, E. R. 2011. Identifikasi kandungan karbohidrat dan protein pada rumput laut (Eucheuma cottoni) Pulau Lombok. Laporan Penelitian Mandiri. Universitas Mataram. Mataram.
Haryanto, B. 2003. Jerami padi fermentasi sebagai ransum dasar ternak ruminansia. Warta Litbang Pertanian 25: 1-3.

Istini, S. A., A. Zatnika, Suhaimi, dan J. Anggadiredja. 1986. Manfaat dan pengolahan rumput laut. Jurnal Penelitian Badan Pengkajian dan Penerapan Teknologi 14: 112.

Mathius, I. W. 2003. Perkebunan kelapa sawit dapat menjadi basis pengembangan sapi potong. Warta Litbang Pertanian 25: 1-4.

Matondang, R. H. dan A. Y. Fadwiwati. 2005. Pemanfaatan jerami jagung fermentasi pada sapi dara Bali (Sistem Integrasi Jagung Sapi). Prosiding. Lokakarya Nasional Tanaman Pakan Ternak, Puslitbang Peternakan. Pp: 104-108.

Pemprov NTB. 2009. Blue Print Nusa Tenggara Barat Bumi Sejuta Sapi (NTB-BSS). Pemerintah Provinsi NTB. Mataram.

Srihardyastutie, A., M. F. Rahman, T. Ardyati, dan I. Prihartini. 2011. Sintesis senyawa fenolik dari lignin ampas tebu menggunakan Bacillus sp. dan uji aktivasinya sebagai bahan anti trombus secara in-vitro. Laporan Penelitian Hibah Bersaing. Universitas Brawijaya, Malang. 